\section{Omfattende bruddskader etter kramper}

Vi leste med stor interesse artikkelen i Tidsskriftet nr. 11/2010 om en 59 år gammel mann som fikk store bekkenskader etter et anfall med kramper på grunn av hypoglykemi (1). Krampeanfall er en relativt vanlig hendelse i sykehjem (2). Mange sykehjemsbeboere har tablettbehandlet diabetes type 2 med fare for hypoglykemi (3), og sykehjemsbeboere har også høy forekomst av osteoporose (4).

Vår pasient var en kvinne i 80-årene som ble innlagt i den ortogeriatriske enheten med omfattende bruddskader. Sykehistorien var uklar og vi var en stund i tvil om dette var en hendelse som burde meldes til politi og helsetilsyn. Imidlertid fikk vi etter noen telefoner til sykehjemmet mer klarhet $\mathrm{i}$ hendelsesforløpet, og et litteratursøk sa oss at slike hendelser forekommer (5). Pasienten hadde diabetes type 2 som var behandlet med perorale antidiabetika 1 . Hun hadde en moderat demenstilstand, var svært lite mobil og måtte hjelpes opp fra seng til stol eller rullestol. Hun fikk så, under morgenstell i seng, et generalisert krampeanfall som forte til respirasjonsstans. Det ble kortvarig gjort hjerte-lungeredning, men hun kom raskt til seg selv. Etter dette var hun medtatt og etter hvert påvirket av smerter $i$ hele kroppen. Hun ble tilsett av lege, men det ble først neste dag reist mistanke om bruddskader, og mobil røntgenundersøkelse ble da rekvirert. Hun hadde disloserte pertrokantære brudd i begge femur samt et dislosert brudd i høyre øvre humerus. Alle brudd ble kirurgisk behandlet i én seanse.

Pasienten kom seg godt og kunne tilbakeføres til sykehjemmet etter ti dager. Under sykehusoppholdet hadde hun hypoglykemi, og antidiabetika ble seponert. Det er imidlertid usikkert om krampeanfallet var forårsaket av hypoglykemi. Dette ble mistenkt i sykehjemmet, og hun fikk derfor sjokolade i munnen når hun våknet til. Blodsukker ble like etter målt til $6,4 \mathrm{mmol} /$ 1. Trolig hadde hun avansert osteoporose. Beintetthetsmåling (DEXA) av ryggsøylen viste ikke nedsatt beintetthet. Målinger kunne ikke gjøres i hoftene på grunn av bruddene, slik at dette ikke ble helt avklart.

Vi mener denne hendelsen viser at ved krampeanfall hos eldre pasienter i sykehjem må man ha i mente at alvorlige bruddskader kan oppstå og at det bør være rutine å undersøke grundig pasienter som har hatt kramper for å se etter bruddskader.

\section{Anette Hylen Ranhoff \\ Ludvig Solheim \\ Diakonhjemmet sykehus}

Oslo

Pasientens hjelpeverge har gitt samtykke til at innlegget blir publisert.
Litteratur

1. Bendiksen C, Emami A, Prytz J et al. En 59 år gammel mann med ryggsmerter etter mulig hypoglykemisk krampeanfall. Tidsskr Nor Legeforen 2010; 130: 1153-5.

2. Rowan AJ. Reflections on the treatment of seizures in the elderly population. Neurology 1998; 51 S28-33.

3. Abdelhafiz AH, Sinclair AJ. Hypoglycaemia in residential care homes. Br J Gen Pract 2009: 59: 49-50. Crilly RG, Hillier LM, Mason M et al. Prevention of hip fractures in long-term care: relevance of com munity-derived data. J Am Geriatr Soc 2010; 58: $738-45$.

5. Vestergaard P. Epilepsy, osteoporosis and fracture risk - a metaanalysis. Acta Neurol Scand 2005; 112: $277-86$.

\section{Screening for kolorektal kreft - endelig en debattant!}

Vi har lenge prøvd å erte på oss folk til debatt om screening for kolorektal cancer. Vi er glad for at Eivind Meland i Tidsskriftet nr. 16/10 har tatt opp hansken (1). Han påpeker at angst og sykeliggjøring kan være et problem ved screening. En av oss (GH) blir kalt «ivrig forkjemper for tarmkreftscreening» med henvisning til et innlegg med en overskrift som bevisst inviterer til motforestillinger. Men hvis man leser hele innlegget, fremgår det at et slikt screeningprogram må tillegges ansvar for utprøvninger, bl.a. av ønskede og uønskede effekter av screening (2). Vi ønsker ikke å ha noen part i et screeningprogram som ikke får et klart mandat til å gjøre noe med kunnskapsmangelen. Innlegget er en erkjennelse av at toget kanskje er gått med tanke på å kunne bidra med ytterligere forskningsbasert kunnskap før man starter screeningprogrammer. Når mange land som vi sammenlikner oss med, har hoppet på kolorektal screening, får vi heller få et program i Norge med mandat for utprøvende virksomhet.

I de norske screeningstudiene av sigmoidoskopiscreening har vi hatt fokus på mulige uheldige virkninger av screening. En av studiene om angst og depresjon etter sigmoidoskopiscreening viste, populært sagt, at «lykken er å bli skopert» og at denne «stemningshevende» effekten holdt seg lenge (3). Dette førte til at vi ble skeptisk til hva screening kunne gjøre med livsstil. Vi fant, som fryktet, at de som ble screenet uten funn av polypper eller kreft $\mathrm{i}$ tarmen, ble mindre motivert for røykekutt og gikk opp i vekt (4). Denne uheldige virkningen av screening ble senere bekreftet $i$ en mer omfattende unders $ø$ kelse (5). Jo mer man screener folk, jo mindre egetansvar synes de å ta for egen helse. Pedagogisk innsats parallelt med screeningen vil muligens rette opp en svekket egeninnsats, men dette må også bli gjenstand for forskning. I motsetning til ved undersøkelse for okklut blod i avføringen er falskt positive tester ved endoskopiscreening ikke noe problem. Legen og pasienten ser der og da om det er en lesjon eller ikke.
Vi mener fortsatt at det er bedre å få screening inn i kontrollerte, evaluerbare former nå - før det er for sent og før vi får amerikanske tilstander med egne screeningklinikker uten kvalitetskontroll.

\section{Geir Hoff}

Sykehuset Telemark

og

Kreftregisteret

Michael Bretthauer

Kreftregisteret

\section{Litteratur \\ - Meland E. Screening og kolorektal kreft. Tidsskr Nor Legeforen 2009; 129: 1876-7. \\ Hoff G. Screening for kolorektalcancer haster. Tidsskr Nor Legeforen 2010; 130: 925. \\ 3. Thiis-Evensen E, Wilhelmsen I, Hoff GS et al. The psychologic effect of attending a screening pro- gram for colorectal polyps. Scand J Gastroenterol 1999: 34: 103-9. \\ 4. Hoff G, Thiis-Evensen E, Grotmol T et al. Do undesirable effects of screening affect all-cause mortality in flexible sigmoidoscopy programmes? Experience from the Telemark Polyp Study 1983-1996. Eur J Cancer Prev 2001; 10: 131-7. \\ 5. Larsen IK, Grotmol T, Almendingen K et al. Impact of colorectal cancer screening on future lifestyle choices: a three-year randomized controlled trial. Clin Gastroenterol Hepatol 2007; 5: 477-83.}

\section{Screening for kolorektal kreft}

Eivind Meland drøfter i en kommentar i Tidsskriftet nr. 16/2010 Helsedirektoratets rolle og håndtering $\mathrm{av}$ forslag til screening for kolorektal kreft. Han viser til et kort intervju med helsedirektøren. Meland diskuterer om leger i myndighetsposisjoner har evne og vilje til etisk refleksjon og etterlevelse av norsk lov.

Insidensen av kolorektal kreft øker kraftig i Norge og er nå høyest i Norden. Innføring av screening er det eneste kjente tiltaket som vil redusere sykelighet og dødelighet ved denne sykdommen.

Nasjonalt råd for kvalitet og prioritering i helsetjenesten drøftet innføring av screening for kolorektal kreft grundig i møter i juni og september 2010. 20. september besluttet rådet enstemmig en forsiktig tilnærming. Rådet anbefalte at det bør startes et pilotprosjekt i ett eller flere geografiske områder, der et tilbud om screening går ut til en avgrenset befolkningsgruppe. Rådet ba videre om at type FOBT-metode og aldersgruppe for utprøvningen vurderes nøye.

Rådet understreket at piloten må gjennomføres med tilstrekkelig prospektiv følgeevaluering slik at man får sikker kunnskap om hvordan et slikt tilbud mottas i befolkningen, hvordan det mest hensiktsmessig kan gjennomføres samt hvilke eventuelle negative følger det kan ha for den enkelte, også sett i et folkehelseperspektiv.

En bred gjennomtenking av denne faglig og etisk komplekse utfordrende problemstillingen har vært nødvendig. Helsedirek- 
toratet følger nå opp saken. Tematikken vil bli belyst og diskutert videre på Nasjonalt råd for kvalitet og prioriterings fagseminar om kreftscreening i slutten av oktober i år.

Bjørn-Inge Larsen

Helsedirektør

\section{Meningsløst om nakkesleng}

Vi må innrømme at vi leser Sven Knagenhjelms innlegg i Tidsskriftet nr. 19/2010

i den pågående nakkeslengdebatten på bakgrunn av hans virke som erstatningsadvokat (1). Vi tror dette også må være grunnen til at han kun siterer for lengst utdatert litteratur om bløtdelsskader, og at han avviser relevansen av nyere studier der man ikke har kunnet påvise noen skadebetingede endringer i nakken med en meget sensitiv teknikk som MR. Når han hevder at «Litauenundersøkelsen» er blitt møtt med «omfattende» kritikk, kan han ikke mene den siste og viktigste litauiske studien, en kontrollert prospektiv kohortundersøkelse (2), som viste at det ikke er er noen langtidsfølger etter vanlig nakkesleng $i$ et land uten erstatningsmuligheter. Denne studien ble publisert i 1999, dvs. etter den av Knagenhjelms siterte «omfattende kritikk». Eller mener han at kritikerne har hatt profetiske evner? Oss bekjent er det etter den prospektive studien fra 1999 ikke publisert en eneste detaljert kritikk $i$ et internasjonalt medisinsk tidsskrift mot dette arbeidet. Istedenfor har enkelte tilhengere av det såkalte kroniske nakkeslengsyndrom valgt å ignorere resultatene $\mathrm{i}$ håp om at de skal gå $\mathrm{i}$ glemmeboken. Det gjør de ikke, og vi takker Knagenhjelm for å gi oss anledning til påny å påpeke at nakkeplagene etter nakkesleng $i$ et land uten erstatningsmuligheter varer gjennomsnittlig tre dager og maksimalt 17 dager, mens hodepinen varer gjennomsnittlig 4,5 timer og maksimalt 20 dager (2).

Når det gjelder Knagenhjelms betraktninger om den nedre grensen for potensielt skadeforvoldende hastighetsendring (delta V) av den påkjørte bil, blir disse meningsløse når han hevder et skadepotensial for hastighetsendringer hvor akselerasjonsbelastningen på nakken er lik eller mindre enn det man er utsatt for gjennom utallige nakkebevegelser i dagliglivets aktiviteter. Dersom man likevel går ut fra de symptomene som er angitt av nakkeslengutsatte, er den nedre potensielle skadegrensen egentlig $0 \mathrm{~km} /$ time, ettersom $20 \%$ av forsøkspersoner også etter en liksompåkjørsel angir akutte eller subakutte symptomer (3). Når man heller ikke krever noen skaderelaterte funn ved objektive undersøkelser, åpner man egentlig for å innføre selvbestemt erstatningsrett, noe norske og åpenbart også danske domstoler i enkelte tilfeller langt på vei synes å ha akseptert. Medisinsk sakkyn- dighet er i så fall overflødig i slike saker, og det er kanskje det Knagenhjelm ønsker?

\section{Harald Schrader}

\section{Lars Jacob Stovne}

Institutt for nevromedisin

Norges teknisk-naturvitenskapelige universitet

\section{Litteratur}

1. Knagenhjelm S. Bløtdelsskader etter lavhastighetskollisjoner. Tidsskr Nor Legeforen 2010 ; 130 : 1908-9.

2. Obelieniene D, Schrader H, Bovim G et al. Pain after whiplash: a prospective controlled inception cohort study. Neurol Neurosurg Psychiatry 1999: 66: $279-83$.

3. Castro WH, Meyer SJ, Becke ME et al. No stress no whiplash? Prevalence of «whiplash» symptoms following exposure to a placebo rear-end ollision. Int J Legal Med 2001; 114: 316-22.

\section{Uansvarlig om fusjonsprosessen på lederplass}

I lederartikler $(1,2)$ og på nett $(3)$ signaliserer Tidsskriftets redaktør bekymring for pasientsikkerhet og ansattes arbeidsmiljø i den pågående fusjonsprosessen ved Oslo universitetssykehus. Hun etterlyser kvalitetsstyring og kommunikasjon mellom grunnplan og ledelse. Disse forholdene er ikke undersøkt i sin helhet, og redaktørens orwellske vyer skaper tvil og usikkerhet blant pasienter og kolleger og i offentligheten. Ord som «desperasjon og fortvilelse», som Legeforeningens representanter bruker i pressen om situasjonen, er vel mer passende i reportasjer fra Pakistan eller Darfur.

Som aktiv kliniker (i hverdagen innen barneanestesi ved Rikshospitalet og i Luftambulansen) og samtidig del av klinikkledelsen ved Akuttklinikken føler jeg et sterkt behov for å nyansere dette.

Jeg er ansvarlig for kvalitetsutvalget ved Akuttklinikken og behandler avvik og klagesaker som kommer til klinikken. Vi har løpet av de første månedene som Oslo universitetssykehus fått et felles elektronisk avvikssystem som sikrer kvalitetsarbeid på tvers, kvalitetsmøter på alle lokalisasjoner og fokus på kvalitet - fra ledelsen og ned. Dokumentasjon fra kvalitetsoppfølging er en obligatorisk del av ethvert oppfølgingsmøte med administrerende direktør og ledelsen ved Oslo universitetssykehus. Alle prosjekter har representanter fra tillitsvalgte og verneombud, og de møter i ledergruppen hver 14. dag. Vi har etablert driftsteam ved operasjonsenhetene ved hele Oslo universitetssykehus. De skal sikre tverrfaglig kvalitet, arbeidsmiljø og effektivt pasienttilbud. Vi har sykmeldingsgruppe som følger endringer i sykefraværet på gruppenivå og intervenerer mot forhold i arbeidsmiljøet som kan påføre ansatte sykdom.

At organisering og utvikling av Oslo universitetssykehus er en vanskelig prosess det er greit. Det handler om visjoner for norsk helsevesen, økonomi og mange delprosesser som tar lengre tid og er mer utfordrende enn mange antar på forhånd. Det kjenner vi på, alle vi som er villig til å ta ansvar for dette. Det handler om å ha vilje og stayerevne til å ta utfordringene.

Mange av oss i ledelsen har tatt tungt ansvar for fag og pasienter i mer enn et kvart århundre. Det vil noen av oss fortsatt gjøre. Mange ledere ved Oslo universitetssykehus har bakgrunn nettopp som tillitsvalgt for Den norske legeforening. Det ville være bemerkesesverdig om vi i fellesskap skulle gå inn for å selge arvesølvet kvalitet for organiseringen av en fremtidsvisjon $i$ vårt helsevesen. Tvert imot er det hensynet til kvalitet og pasientsikkerhet som bestemmer hastigheten på denne prosessen.

Dette burde lyse som en rød lampe til advarsel over redaktørens frie resonnementer om svikt i kvalitet og lederskap.

Pasientsikkerhet og kvalitet ofres ikke, og det foreligger en indre debatt og egne fora i Oslo universitetssykehus der ansatte møter ledelse. For min del møter jeg kolleger formelt og uformelt daglig - ved sykesengen, i korridoren eller på kontoret.

Virkeligheten svarer med andre ord ikke til innholdet av Charlotte Haugs meldinger til alle landets leger fra lederplass. Det er viktig for redaktøren å se sin stilling i dette perspektiv. Det er en mektig posisjon i norsk helsevesen å kunne forme en lederartikkel i Tidsskriftet! Tidsskriftet er når som helst velkommen til å komme til oss for å prøve å se helheten i dette før neste melding kommer!

\section{Øyvind Skraastad}

Oslo universitetssykehus, Rikshospitalet

\section{Litteratur \\ 1. Haug C. Makten i uklare formuleringer. Tidsskr Nor Legeforen 2010; 130: 1701 \\ Haug C. Faremelding: Understrømmer. Tidsskr Nor Legeforen 2010; 130: 1805 \\ 3. Haug C. Farlig taushet ved Oslo universitetssyke- hus. http: //blogg.tidsskriftet.no/2010/09/} oslo-universitetssykehus/ (6.10.2010). 